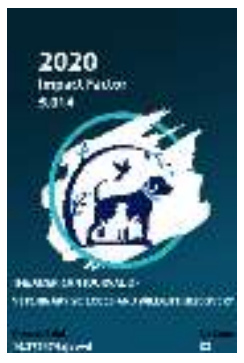

Journal Website: http://usajournalshub.c om/index,php/tajvswd

Copyright: Original content from this work may be used under the terms of the creative commons attributes 4.0 licence.

\section{Systematics Of Paramphistomatosis, Methods Of Diagnosis, Epizootology, Pathogenesis, Origin Of The Disease And New Methods Of Treatment}

\author{
Avezimbetov Sh. \\ Candidate Of Veterinary Sciences, Nukus Branch Of Samarkand Institute Of Veterinary \\ Medicine, Uzbekistan
}

Taylakov T.I.

Candidate Of Veterinary Sciences, Samarkand Institute Of Veterinary Medicine, Uzbekistan

\title{
ABSTRACT
}

This article describes paramphistomatosis of large and small horned domestic animals, its systematics, and methods of helminthocaprological examination, paramphistomatosis found in the large and retinal abdomen of dead and forcibly slaughtered animals, stages of ovulation in mollusks, pathogenesis, pathological and anatomical changes and treatment reported.

\section{KEYWORDS}

Paramphistomatosis, preimaginal, definitive, invasive intensity, helminth, sporocyst, helminthoovoscopic.

\section{INTRODUCTION}

Paramphistomatosis is a gastrointestinal trematodosis of large and small horned domestic animals, as well as ruminant doublehoofed wild herbivorous mammals in acute and chronic flows. The first preimaginal period of their stimuli takes place under the anterior section of the small intestine of the definitive hosts and under the mucous membranes of the larynx. Young parasites cause severe catarrhal and hemorrhagic inflammation in these digestive organs and provoke an acute course of the disease. Mortality is observed in animals with high levels of invasive intensity. Deaths and forced slaughter of cattle have been observed for many years. For the first time in recent years, deaths from paramphistomatosis have also been observed among sheep (Salimov et al., 2012, 2015). In animals surviving the acute course of paramphistomatosis, 
young trematodes move in reverse to mature, reproduce, and continue a parasitic lifestyle, moving to the anterior part of the digestive tract, including the large abdomen (rumen) and partly to the reticulum, parasitizes the mucous membranes. Adult and, in part, paramphistomats that have not yet reached this level, trigger a chronic course of the disease. The disease is very dangerous even in this stream, if the number of parasites is too large.

\section{THE MAIN FINDING AND RESULTS}

Paramphistomatosis is one of the most dangerous helminthiases in the world. They are found in Australia, America, Africa, Europe and Asia.

More than 100 types of paramyfistomatous pathogens are known in science. The first to study them and determine their place in the systematics of helminths was the German scientist Rudolphi in 1801, who introduced all paramphistomas into the Amphistoma lineage. In 1808, he divided this generation into two groups: the first group included trematodes with a head, and the second group included trematodes with a continuation of the body. In 1819, the trematodes belonging to the second group of Amphistomas were described as follows: trematodes with a slightly flattened body, a small-sized urticarial, a mouth in the anterior part of the body, and a deformable sucker in the posterior part. In 1847, Creplin created the Amphistoma crumenifer species of the Amphistoma genus for such trematodes parasitizing the anterior abdomen of ruminants, and the Poirier created the Gastrothylax genus for this species.

Beginning in 1901, work began on improving the system of paramphistomats. That same year, a German researcher, Fischoeder, suggested that the Amphistoma lineage be called the Paramphitomum lineage. He included all the paramphistomats known to science at the time into a single family, naming it the Paramphitomatidae Fischoeder, 1901 family. This family is still preserved as the largest family in the Paramphitomata subfamily. In 1910, Stiles et Goldberger added the Gastrothylacidae family to the group of paramphistomats. In 1934, Travossos created a new systematics of paramphistomas. According to him, the current subspecies Paramphistomata since 1937 has included 3 families, 13 subspecies, 46 genera and 105 species. However, until 1937, there were also conflicting systematic groups in the diagnosis of parasitic trematodes in the anterior part of the stomach by various researchers. Accordingly, in 1937, the Swedish scientist Nesmark (Näsmark) completely revised the systematics of paramphistomats and developed a new system for identifying species. According to him, he recommended the study of the muscular system of trematodes, the structure of the abdominal sucker and the sexual cloaca (atrium). Based on the study of the anatomo-morphology of exactly the same 3 organs, Nesmark substantiated the independence of the species and divided them into appropriate systematic groups. The structure of the muscular organs of paramphistomats by Nesmark is of great taxonomic importance. While the structural types of the abdominal cavity are the diagnostic marker of the generation, the histological structure of the pharynx (larynx) and genital cloaca is the basis for determining the species composition of paramphistomats.

Szidat in 1936, K.I.Skryabin and R.S.Shults in 1937, due to a careful study of several families, formed the large Paramphistomata (Szidat, 1936) Skrjabin et Schulz, 1937 junior series. In doing so, Szidat took into account the similarity of the developmental cycle of gastric 
trematodes, while K.I. Scriabin and R.S. Schultz based their morphology on the diagnostic features created by Nesmark.

Continuing to study paramphistomats has led to the creation of new generations. In the territory of Uzbekistan identified parasitic species of trematodes belonging to the following two families among large and small horned animals:

Family: Paramphistomatidae Fischoeder, 1901

Generation: Paramphistomum Fischoeder, 1901

Paramphistomum ischikawai Fukui, 1922

Generation: Liorchis Velichko, 1966

Liorchis scotiae (Willmott, 1950)

Liorchis hiberniae (Willmott, 1950)

Generation: Calicophoron Näsmark, 1937

Calicophoron calicophorum (Fischoeder, 1901)

Calicophoron erschowi Davydova, 1959

Family: Gastrothylacidae Stiles et Goldberger, 1910

Generation: Gastrothylax Poirier, 1883

Gastrothylax crumenifer (Creplin, 1874)

Paramphistomatosis is widespread in irrigated and foothill biocenoses in Uzbekistan. Almost all water bodies in these areas used as pastures - lakes, springs, springs, drainage canals, various irrigation canals, swamps, rice fields are biotopes of mollusks belonging to the intermediate hosts of their pathogens Planorbidae family. The source of invasion of these soft-bodied animals, which is caused by the larvae of this or that paramphistomatous pathogen, is infected animals. In areas unhealthy for paramphistomatosis, parthenites of pathogens overwinter in the body of the intermediate host, and they become a source of invasion for animals from the spring season onwards. This year, adolescariae formed from cercariae in molluscs infested with parasitic pathogens are a source of invasion for definitive hosts of parasites in summer, autumn, and even winter. Feeding animals on pasture during the warm winter months or feeding them with roughage collected from unhealthy areas can also lead to invasion by paramphistomats. Many years of observations have until recent years led to paramphistomatosis being considered a disease specific to large horned animals. In the territory of Uzbekistan, the strongest infestation of cattle with this or that pathogen was first observed in the north-western part of the Republic of Karakalpakstan, Khorezm region, and then in the southernmost region, Surkhandarya region in the 6os and 70 s of the last century. In Karakalpakstan, gastrothylaxis is widespread, and in Surkhandarya region, kalycophorosis. The average rate of infestation of cattle with the gastrotylaxosis pathogen was $16.0 \%$, but its average invasive intensity was 2387 copies of the parasite, and in some animals the number of parasites reached 121766 copies. In some farms, the invasiveness of gastrothylaxosis in cattle was $92.2 \%$. A slight increase in invasive intensity and invasiveness was observed with the age of the animals. (Ruziev, 1970) The epizootiological significance of gastrogylaxosis has been lost in recent years as a result of the aggravation of the ecological situation in Karakalpakstan, including the tragedy of the Aral Sea and the drying up of many lakes due to droughts. Avezimbetov, 2007)

\section{RESEARCH MATERIALS AND METHODS}

Paramphistomats are detected by sequential washing of feces during animal survival. It is 
enough to take 3-5 g of feces for examination. The resulting sample is mixed with 10 times the amount of water in a porcelain mortar. It is then passed through a metal strainer (holes with a diameter not exceeding $0.19 \mathrm{~mm}$ ) or a single layer of gauze. The sample is allowed to stand for 10 minutes. It depends on the composition of the feces. For example, cattle faeces are poorly washed during the grazing period and require 12 to 13 minutes of rest. After this time, the top of the liquid is slowly drained, the rest is poured with clean water and allowed to stand for another 5-8 minutes, and this process is repeated until the top of the liquid is clear. Finally, the top of the liquid is drained, and the precipitate (around $5 \mathrm{ml}$ ) is examined under a microscope.

The mature eggs are oval in shape; the inside of the egg is not completely filled with yolk cells, unlike the eggs of fasciolia. Color gray, size 0.11$0.16 \times 0.07-0.08 \mathrm{~mm}$.

Intermediate hosts of paramphistomats are freshwater mollusks. Their parthenogenetic development takes place in soft-bodied animals belonging to the family Planorbidae with cochlear shells. Adult paramphistomats begin to multiply sexually. As a result, the fertilized egg is released into the external environment. Eggs exposed to the aquatic environment are ciliated hereditary at $19-27 C$. Such first-generation larvae hatch from eggs and actively break into the body of the intermediate host-mollusk. In her body, she loses her eyelashes and other organs and becomes a second-generation larval sporocyst. From the embryonic cells of the sporocyst, 3rd generation larvae-reds are formed parthenogenetically without fertilization. It is through this development that the cercariae begin to mature from the radishes. This process takes a long time, resulting in a large number of cercariae growing from each infected mollusk. This is evidenced by the parasitism of several tens of thousands of paramphistomats in the body of each definitive host. The duration of release of cercariae from the mollusk organism into the external environment depends on the temperature of the water in the habitat in which it lives, and it begins 1.5-3 months after the intermediate host is infected. Cercariae mainly become adolescarii after undergoing a period of cystogony on the surface of aquatic plants Definitive hosts are infected with paramphistomats as a result of ingestion of such adolescaria by grass and partial water. Young parasites enter the mucous membranes of the small intestine and small intestine and go through a period of tissue survival. They then return to the large abdomen, rarely to the retina, as they mature. The maritogonia period of paramphistomas lasts 3-4 months; adult trematodes live at least 4-5 years.

\section{RESEARCH RESULTS}

According to our research, Gastrothylax crumenifer parasitizes about 10,000 in the large and retinal abdomen of some dead and forcibly slaughtered animals in the first severe outbreaks of paramphistomatosis.

Pathogenesis: Young paramphistomats cause pathological processes in the small intestine and urethra during parasitism, disrupt the digestive process. Adult and young parasites poison the host organism with their unwanted products. Paramphistomas parasitizing in the anterior part of the stomach inflame the mucous membranes of the large abdomen. In paramphistomatosis, the number of erythrocytes in the blood and the amount of hemoglobin decreases, leukocytosis develops.

Pathological and anatomical changes: Catarrhal-hemorrhagic inflammation, thinning of the body, whitening of the mucous 
membranes is observed during the parasitism of young paramphistomats in the small intestine and urethra. In the anterior part of the small intestine, especially in the duodenum, there are thousands of young parasites, which cause the intestine to expand, the wall to thicken, swell, and the serous membrane to become red.

In chronic paramphistomatosis, enlargement of the jaw and breasts, infiltration, atrophy of the villi of the anterior part of the stomach, erosion of the surface layer (easy migration) are observed.

Treatment: Paramphistomatous pathogens are resistant to anthelmintics. For this reason, albendazole drugs currently used against all trematodes do not work well against them. Special drugs recommended for paramphistomatosis also do not show adequate results. Even if you increase their amount by at least 3-4 times, you will not get $100 \%$ efficiency. Therefore, it is necessary to improve the treatment of paramphistomatosis.

In the conditions of Uzbekistan paramphistomatosis has a high invasive intensity and the causative agents are other types of trematodes. In such conditions, the use of albendazole anthelmintics containing clozantel or oxyclozanite in the treatment of paromfiztomatosis can be increased by 2-3 times and re-applied up to 3 times in 10-15 days. Such anthelmintics include fascoside containing oxyclozanite and albendazole, helmicite, albasafe, alben or clozalben containing clozantel and albendazole - 10 drugs. All this shows that the search for new drugs against paramphistomatosis and the improvement of methods of their application is a requirement of the times.

\section{CONCLUSION}

Diagnosis of paramphistomatosis in living animals is made on the basis of their clinical signs, epizootiological data, the results of helminthoovoscopic (in the case of chronic) examination. Helminthoovoscopy is performed by sequential washing of animal dung. Paramfistomat eggs should be distinguished from fasciola eggs by color, size, and shape.

\section{REFERENCES}

1. [1] Ergashev E.H., Abduraxmonov T.A. Chorva mollarining gelmintozlari. O'quv qo'llanma. Toshkent, «Mehnat», 1992 yil. (Ergashev E.H., Abdurakhmonov T.A. (1992) Livestock helminthiasis. Study guide. - Tashkent. “Labor”.)

2. [2] Haqberdiev P.S., Qurbanov Sh.X. Parazitologiya fanidan amaliy va laboratoriya mashg'ulotlari. O‘quv qo'llanma. Toshkent, 2015 yil. (Haqberdiev P.S., Qurbanov Sh.X. (2015) Practical and laboratory classes in parasitology. Study guide. - Tashkent)

3. [3] Ergashev E.H. va boshqalar. Umumiy parazitologiya. O’quv qo'llanma. Samarqand, 1999 yil. (Ergashev E.H. and others. (1999) General parasitology. Study guide. - Samarkand)

4. Abuladze K.I. Parasitology and invasive diseases of animals. Textbooks and tutorials. Moscow, "Agropromizdat", 1990. (Abuladze K.I. (1990) Parasitology and invasive diseases of animals. Textbooks and tutorials. Moscow, "Agropromizdat".)

5. Shustrova M.V. Parasitology and invasive diseases of animals. Textbook. Russia, "Kolos", 2006. (Shustrova M.V. (2006) Parasitology and invasive diseases of animals. Textbook. - Russia. "Kolos".)

6. Yatusevich A.I. Parasitology and invasive diseases of animals. Textbook. Minsk, "ITC 
of the Ministry of Finance", 2017. (Yatusevich A.I. (2017) Parasitology and invasive diseases of animals. Textbook. Minsk. "ITC of the Ministry of Finance")

7. Denis Jacobs, mark Fox, Lynda Gibbons, Carlos hermosilla. Principles of Veterinary Parasitology. Wiley Blackwell, USA, 2016 year.

8. Veterinariya meditsinasi jurnallari. Toshkent. (Journal of Veterinary Medicine. - Tashkent)

9. Internet saytlari (Internet resources): www.ziyo.net.uz; www.vetgov.uz; www.samvmi.uz; www.vetjurnal.uz; www.fvat.academy.uzsci.net. 